\title{
Undergraduate Attitudes toward Business Ethics: A Cross-Cultural Comparison
}

\author{
Robert Shields (Corresponding author) \\ The Institute of Electrical and Electronics Engineers \\ E-mail: lymrcs@ieee.org \\ Charles Comegys \\ Merrimack College \\ Robert Lupton \\ Central Washington University \\ Hideki Takei \\ Central Washington University
}

Received: August 25, 2013 Accepted: September 14, 2013 Published: November 1, 2013

doi:10.5296/jse.v3i4.4179

URL: http://dx.doi.org/10.5296/jse.v3i4.4179

\begin{abstract}
This study builds on prior work on the effect of demographic variables on undergraduate attitudes towards business ethics and examines differences between US and Japanese students sampled in 2011. The samples comprised 89 US and 147 Japanese undergraduate students (n-236). Respondents completed the Attitude Towards Business Ethics (ATBEQ) questionnaire and demographic questions. Data were analyzed with SPSS ANOVA, post-hoc t-tests and with non-parametric tests. Significant Japanese and US student samples differed significantly $(p<0.05)$ on at least fifty percent of ATBEQ statements. The Japanese students expressed significantly stronger agreement with seven Machiavellian and three Social Darwinism statements whereas the US students expressed significantly stronger agreement with only two Machiavellian and one Social Darwinism statements.
\end{abstract}

Keywords: Business Ethics, Ethical Attitudes, Business Education 


\section{Introduction}

Calls to increase ethical behavior in business practice and in teaching students ethical business practices abound; see, Sims \& Gregez 2004. Corporate survey data collected by Labaton Suchrow LLP in 2012 indicates that "approximately one fourth of executives believe that one must break rules to be successful; approximately one third feel pressured by compensation plans to violate rules or ethical principles and approximately 16 percent would commit a crime such as insider trading if they knew they could do so without getting caught."

Prior work (Comegys, et. al 2012) compared US undergraduate attitudes measured in 2007 and 2011 and found differences based on demographic factors such as gender. It also found significantly less agreement with Machiavellian attitudes among 2011 students than among 2007 students. This suggests that educators have helped some students shift attitudes away from sheer opportunism. Kuntz et al. (2013) found general ethical attitudes to be lower in Russian samples than samples in Western countries like New Zealand and variables such as gender and managerial experience influence the way people interpret ethical issues.

The current work was undertaken to compare US and Japanese student attitudes towards business ethics as well as uncover possible influencing variables such as gender and age.

\section{Literature Review}

The ATBEQ statements were presented by Preble \& Reichel (1988). The questionnaire consists of thirty statements with a five point Likert scale to indicate agreement or disagreement with each item. The scale ranges from 1 "disagree strongly to 5 "agree strongly.” Bageac (2011) listed each statement as belonging in one of five philosophical categories. The categories progressed from most self-oriented to least self-oriented or more benign: Machiavellian, Social Darwinism, Ethical Relativism, Legalism and Moral Objectivism. (One might argue that the Legalism philosophy is not benign in situations where the laws or rules are inequitable, that discussion is beyond the scope of this paper.) See Table 1 for the list of ATBEQ statements and their philosophical categorization.

Table 1. ATBEQ as cited in Preble, J. and Reichel A. (1988). Philosophical Categories as presented in Bageac (2011): $(\mathrm{M})=$ Machiavellian, $(\mathrm{S})=$ Social Darwinism, $(\mathrm{E})=$ Ethical Realism, $(\mathrm{L})=$ Legalism, $(\mathrm{O})=$ Moral Objectivism

\begin{tabular}{|l}
\hline 1. \\
\hline (M) The only moral of business is making money. \\
(M) A person who is doing well in business does not have to worry about moral \\
problems. \\
\hline 3. \\
(O) Every business person acts according to moral principles, whether he/she is \\
aware of it or not. \\
\hline $4 . \quad$ (L) Act according to the law, and you can't go wrong morally. \\
\hline 5. \\
(E) Ethics in business is basically an adjustment between expectations and the way \\
people behave. \\
(M) Business decisions involve a realistic economic attitude and not a moral \\
philosophy.
\end{tabular}




\begin{tabular}{|c|}
\hline 7. (M) Moral values are irrelevant to the business world. \\
\hline 8. (E) The lack of public confidence in the ethics of business people is not justified. \\
\hline 9. (S) "Business ethics" is a concept for public relations only. \\
\hline $\begin{array}{l}\text { 10. (S) The business world today is not different from what it used to be in the past. } \\
\text { There is nothing new under the sun. }\end{array}$ \\
\hline $\begin{array}{l}\text { 11. (S) Competitiveness and profitability are independent values (existing on their } \\
\text { own). }\end{array}$ \\
\hline $\begin{array}{l}\text { 12. (S) Conditions of a free economy will serve best the needs of society. Limiting } \\
\text { competition can only hurt society and actually violates basic natural laws. }\end{array}$ \\
\hline $\begin{array}{l}\text { 13. (S) As a consumer when making a car insurance claim, I try to get as much as } \\
\text { possible regardless of the extent of the damage. }\end{array}$ \\
\hline $\begin{array}{l}\text { 14. (S) While shopping at the supermarket, it is appropriate to switch price tags or } \\
\text { packages. }\end{array}$ \\
\hline 15. (S) As an employee, I take office supplies home; it doesn’t hurt anyone. \\
\hline 16. (S) I view sick days as vacation days that I deserve. \\
\hline $\begin{array}{l}\text { 17. (S) Employee wages should be determined according to the laws of supply and } \\
\text { demand. }\end{array}$ \\
\hline 18. (S) The main interest of shareholders is maximum return on their investment. \\
\hline $\begin{array}{l}\text { 19. (M) George X says of himself, "I work long, hard hours and do a good job, but it } \\
\text { seems to me that other people are progressing faster. But I know my efforts will } \\
\text { pay off in the end." Yes, George works hard, but he's not realistic. }\end{array}$ \\
\hline $\begin{array}{l}\text { 20. (M) For every decision in business the only question I ask is, "Will it be } \\
\text { profitable?" If yes - I will act according; if not, it is irrelevant and a waste of } \\
\text { time. }\end{array}$ \\
\hline $\begin{array}{l}\text { 21. (M) In my grocery store every week I raise the price of a certain product and mark } \\
\text { it "on sale". There is nothing wrong with doing this. }\end{array}$ \\
\hline 22. (M) A business person can’t afford to get hung up on ideals. \\
\hline $\begin{array}{l}\text { 23. (M) If you want a specific goal, you have got to take the necessary means to } \\
\text { achieve it. }\end{array}$ \\
\hline 24. (M) The business world has its own rules. \\
\hline 25. (M) A good business person is a successful business person. \\
\hline $\begin{array}{l}\text { 26. (O) I would rather have truth and personal responsibility than unconditional love } \\
\text { and belongings. }\end{array}$ \\
\hline 27. (O) True morality is first and foremost self-interested. \\
\hline 28. (O) Self-sacrifice is immoral. \\
\hline 29. (O) You can judge a person according to his work and his dedication. \\
\hline 30. (O) You should not consume more than you produce. \\
\hline
\end{tabular}

There is considerable work investigating business ethics issues within the US and internationally. Lu (2009), looking beyond domestic needs posited that educators can draw on ethical traditions to spur both legal and behavioral consistency in professional standards. He 
presents such consistency as prudent and essential to reduce ethical conflict between diverse cultures.

Bageac et. al. (2011) used the Attitudes Toward Business Ethics Questionnaire (ATBEQ) to compare attitudes of European management students from France and Romania (n-220). They found Romanian student showed more favorable attitudes toward the Machiavellian items and French students toward Social Darwinism and Moral Objectivism. That paper placed each ATBEQ statement into one of the five philosophical categories. Extending and confirming multiple prior research findings, Kennedy \& Kray (2013) found significant differences in reaction to ethical compromise situations based on gender.

Using the ATBEQ to assess change over a 16-year period, Price and van der Walt (2013) found stronger opinions expressed by more recent South African students than by earlier students (n-142). Moreover, the recent students were more likely to agree with teleological and utilitarian (results based) philosophies that appeared grounded in compliance based ethics rather than internal, ego based philosophy. That paper postulated the cause of the differences to include increased regulation and desire to reduce the negative effects of potential damage to organizational reputation.

Lau, Cubie L.L. (2010) found that ethics education significantly improved ethical awareness and moral reasoning (n-707). That work used the ATBEQ and a set of ethical vignettes to compare students that had had ethical training with those that had not had the training. He also found that $66 \%$ of students that had not had the training (versus $88 \%$ of those that had experienced the training) thought a business ethics course should be included in the business curriculum.

Some prior work comparing international attitude data has adopted stringent criteria for determining meaningful differences in attitudes. Moore (1996) believed that the criteria for significance or meaningfulness must use the cumulative effect of the ATBEQ response differences rather than merely using one question at a time. They asserted that at least 50 percent of the ATBEQ attitude statements must show statistically significant differences to ascertain significant or meaningful differences in ethical business attitudes between national samples (Moore \& Radloff, 1996, p. 868).

The studies described above encourage us to note how a range of cultural and demographic differences could affect attitudes towards business ethics and set a rigorous criteria for assessing the meaningfulness of measured differences in attitudes.

\section{Research Questions and Hypotheses}

Does student country, gender, age or ethics classes effect attitudes towards business ethics.

H1: Attitudes toward business ethics will not differ by location/country

H2: Attitudes toward business ethics will not differ by gender

H3: Attitudes toward business ethics will not differ by age

H4: Attitudes toward business ethics will not differ by number of ethics classes taken 


\section{Methodology}

The US data were gathered from classes at a university in the Northwest region of the United States. The questionnaires were distributed in classes to produce a convenience sample. This convenience sample of 89 undergraduate students included 31 women (35.2 percent) and 58 male students. The average age of the respondents was 22.74 years and the age range was 19 to 35 years old.

This sample of 147 undergraduate students included 55 women ( 34.7 percent) and 92 men. The average age was 19.04 and the age range was 18 to 23 years old.

These research questions were examined using SPSS methods to analyze the ATBEQ and demographic data. Meaningful significant differences were determined using the cumulative impact criterion set by Moore \& Radloff (1996). According to that criterion, analysis must find statistically significant response differences on 50 percent or more of the statements to be considered meaningful.

The survey instrument for the current study included the ATBEQ (see Appendix 1), and questions to gather demographic and additional information such as gender, age, GPA year in school and number of ethics courses completed.

To conclude meaningful significant differences, these following conditions must be met. First, the analysis must provide a significant result at $\mathrm{p}<0.05$. Second, ad-hoc significance levels between two sets must be $\mathrm{p}<0.05$. Third, significant differences must be found on at least 50 percent of the ATBEQ statements to be deemed meaningful overall since agreement with the ATBEQ statements are assessed with a Likert scale, the count of t-test differences must be confirmed with non-parametric tests

\section{Results}

First, we will show the results of the Differences between USA and Japan. Using the conditions stated above, there were differences in the mean levels of agreement with ATBEQ statements on over 50-percent of the statements. ANOVA and Pair wise t-testing revealed 16 statements with significant differences between the two sets of students $(1,2,5,8,9,11,14$, $17,18,20,21,22,23,24,27$, and 28).

The SPSS t-test analysis found significantly different mean statement agreement values collected from Japanese students that were higher than those collected from US students on 14 items (1, 2, 5, 8, 9, 14, 17, 18, 20, 21, 22, 24, 27, and 28). The mean statement agreement was significantly greater for US students on only 2 items (11 and 23). The non-parametric, Mann-Whitney $\mathrm{U}$ test analysis also found 16 significantly different medians.

Now, we will show the rsults of differences based on gender, age and wthics classes taken. None of the other null hypotheses could be rejected because none showed differences in mean agreement on at least half of the statements. None of the analyzed combinations of independent variables showed differences in mean agreement on at least half of the statements. 
For Japanese students, there were nine statements with significant agreement differences based on gender. For US students, there were five statements with significant agreement differences based on gender.

\section{Discussion and Conclusion}

The impact of data collection country (Japan versus United States) on student attitudes toward business ethics was supported on 16 of the 30 ATBEQ statements.

The lack of significant gender difference suggests that as of 2011, male students presented less extreme beliefs than were found in prior samples. This may reflect more homogeneity in male student beliefs or a desire to appear more acceptable in light of the negative publicity associated with corporate ethical lapses.

The data collected from students in Japan showed stronger agreement than that of students in the US on the following 14 items (1, 2, 5, 8, 9, 14, 17, 18, 20, 21, 22, 24, 27, and 28). According to the categorization described above seven of these (1, 2, 9, 20, 21, 22, and 24) indicate preferences for Machiavellian philosophy. Three items indicate a preference for Social Darwinism (14, 17, and 18). Only two (27 and 28) indicate a preference for Moral Objectivism. Thus the bulk of these stronger agreements by Japanese students were, philosophically, less benign than those of the US students.

The results presented above suggest that the attitudes toward business ethics of the students in the US and Japan differ significantly. Based on the correspondence between ABETQ items and philosophies, it appears that US students' expressed attitude towards ethics is less self-serving.

Results from the work reported in this paper suggest that Japanese students in 2011 had not adopted as benign a set of ethical attitudes at the same rate as their US counterparts. This may imply a need to enhance coverage of ethical principles in international curricula to strengthen students' abilities to recognize and apply ethical thinking more broadly and effectively.

\section{Recommendation}

Future work could compare US student attitudes with those of students in other countries. It would be useful to determine if significant changes have occurred in a range of locations compared to data gathered before the recent recession. Collecting repeated sample data for students before and after completion of an ethics course could help demonstrate the effects of targeted education on ethical attitudes. The authors plan to continue longitudinal data collection and comparison.

\section{References}

Aggaral, P., Vaidyanathan, R., \& Castleberry, S. (2012). Managerial and Public Attitudes Toward Ethics in Marketing Research. Journal of Business Ethics, 109, 463-481. http://dx.doi.org/10.1007/s10551-011-1140-2

Arlow, P. (1991). Characteristics in college students' evaluations of business ethics and corporate responsibility. Journal of Business Ethics, 10, 63-69. 
http://dx.doi.org/10.1007/BF00383694

Bageac, D., Furrer, O. \& Reynaud, E. (2011). Management Students' Attitudes Toward Business Ethics: A Comparison Between France and Romania. Journal of Business Ethics, 98, 391-406. http://dx.doi.org/10.1007/s10551-010-0555-5

Borkowski, S.C. \& Y.J. Ugras (1992). The ethical attitudes of students as a function of age, sex, and experience. Journal of Business Ethics, 11, 63-69. http://dx.doi.org/10.1007/BF00871962

Childers, T.L. (1986). Assessment of the Psychometric Properties of an Opinion Leadership Scale. Journal of Marketing Research, 23, 184-188. http://dx.doi.org/10.2307/3151666

Comegys, C., Lupton, R.A., Takei, H. \& Shields, R. (2012). Undergraduate Attitudes Toward Business Ethics, Proceedings of the Marketing Educators' Association Conference, Long Beach, CA

Dierksmeir, C. (2013). Kant on Virtue. Journal of Business Ethics, 113, 597-609. http://dx.doi.org/10.1007/s10551-013-1683-5

Ethics Education Task Force to AACSB International, Ethics Education in Business Schools (2004.) St. Louis, MO AACSB International.

Ferrell, O. (1999) An Assessment of the Proposed Academy of Marketing Science Code of Ethics for Marketing Educators. Journal of Business Ethics, 19, 225-228. http://dx.doi.org/10.1023/A:1005953209391

Forelle, C. \& J.Bandler (2006). The Perfect Payday; Some CEOs reap millions by landing stock options when they are most valuable; Luck - or something else? The Wall Street Journal, New York.

Glenn, J.R. (1992). Can a business and society course effect the ethical judgment of future managers? Journal of Business Ethics, 11(3), 217-224. http://dx.doi.org/10.1007/BF00871969

Grunbaum, L. (1997). Attitudes of Future Managers Towards Business Ethics: A Comparison of Finnish and American Business Students, Journal of Business Ethics, 16(4), 451-463. http://dx.doi.org/10.1023/A:1017909311756

Hill, R. P. (1995). Researching Sensitive Topics in Marketing - The Special Case of Vulnerable Populations. Journal of Public Policy \& Marketing, 14(1), 143-49.

Kennedy, J. A., \& Kray, L. J. (2013) Who Is Willing to Sacrifice Ethical Values for Money and Social Status?: Gender Differences in Reactions to Ethical Compromises. Available at: http://spp.sagepub.com.

Kuntz, J. R. C., Kuntz, J. R., Elenkov, D., \& Nabrukhina, A. (2013). Characterizing Ethical Cases: A Cross-Cultural Investigation of Individual Differences, Organizational Climate, and Leadership on Ethical Decision-Making. Journal of Business Ethics, 113, 317-331. http://dx.doi.org/10.1007/s10551-012-1306-6 
Lau, Cubie L.L. (2010). A Step Forward: Ethics Education Matters! Journal of Business Ethics, 92, 565-584. http://dx.doi.org/10.1007/s10551-009-0173-2

Lin, C. (1999). A Comparison of Perceptions About Business Ethics in Four Countries. The Journal of Psychology, 133(6), 641-655. http://dx.doi.org/10.1080/00223989909599770

Lu, Xiaohe (2009). A Chinese Perspective: Business Ethics in China Now and in the Future. Journal of Business Ethics, 86, 451-461. http://dx.doi.org/10.1007/s10551-008-9857-2

Miesing, P. \& Preble, J.F. (1985). A comparison of five business philosophies. Journal of Business Ethics, 4, 465-476. http://dx.doi.org/10.1007/BF00382609

Moore, R. and Radloff, S. (1996). Attitudes Towards Business Ethics Held by South African Students. Journal of Business Ethics, 15, 863-869. http://dx.doi.org/10.1007/BF00381854

Okleshen, M. \& R. Hoyt (1996). A cross cultural comparison of ethical perspectives and decision approaches of business students: United States of America versus New Zealand. Journal of Business Ethics, 15, 537-549. http://dx.doi.org/10.1007/BF00381929

Phau, Ian and Kea, Garick. (2007). Attitudes of University Students toward Business Ethics: A Cross-National Investigation of Australia, Singapore and Hong Kong. Journal of Business Ethics, 72, 61-75. http://dx.doi.org/10.1007/s10551-006-9156-8

Preble, J. and Reichel A. (1988). Attitudes Towards Business Ethics of Future Managers in the U.S. and Israel. Journal of Business Ethics, 7, 941-949.

Price, G. and van der Walt, A.J. (2013). Changes in Attitudes Towards Business Ethics Held by Former South African Business Management Students. Journal of Business Ethics, 113, 429-440. http://dx.doi.org/10.1007/s10551-012-1314-6

Robinson, B., Stey, P., \& Alfano, M. (2013). Virtue and Vice Attribution in the Business Context: An Experimental Investigation. Journal of Business Ethics, 113, 649-661. http://dx.doi.org/10.1007/s10551-013-1676-4

Rundle-Thiele, S. R. \& W. Wymer (2010). Stand-Alone Ethics, Social Responsibility and Sustainability Course Requirements: A snapshot From Australia and New Zealand. Journal of Marketing Education, 32(1) 5-12. http://dx.doi.org/10.1177/0273475309345002

Sims, R. \& Gegez A. E. (2004). Attitudes Towards Business Ethics: A Five Nation Comparative Study. Journal of Business Ethics, 50, 253-265. http://dx.doi.org/10.1023/B:BUSI.0000024708.07201.2d

Small, M. (1992). Attitudes Towards Business Ethics Held by South African Students. Journal of Business Ethics, 11, 745-752. http://dx.doi.org/10.1007/BF00872306

Stevens, E. (1979). Business Ethics, Paulist Press, New York / Ramsey.

Stevens, G. (1984). Business ethics and social responsibility: The responses of present and future managers. Akron Business and Economics Review, 15, 6-11. 


\section{Copyright Disclaimer}

Copyright reserved by the author(s).

This article is an open-access article distributed under the terms and conditions of the Creative Commons Attribution license (http://creativecommons.org/licenses/by/3.0/). 